\title{
Conyza sumatrensis Allelopathy EFFECt on Bidens PILOSA (ASteRACEAE) SEed
} GERMINATION

\section{EFECTO ALELOPÁTICO DE CONYZA SUMATRENSIS SOBRE LA GERMINACIÓN DE SEMILLAS DE BIDENS PILOSA (ASTERACEAE)}

\author{
@Paulo José Ferreira, @Patrícia da Costa Zonetti, @Alfredo Junior Paiola Albrecht, @isac George Rosset, \\ ๑André Felipe Moreira Silva**, @leandro Paiola Albrecht, @Amanda Holz Vieira, @Roberta Paulert
}

Universidade Federal do Paraná, Palotina, state of Paraná, Brazil

*Corresponding author: afmoreirasilva@hotmail.com

\begin{abstract}
Background: Other tools for weed management should be considered in addition to the use of herbicides. In this context, the identification and use of allelopathic compounds deserves attention.

Question: To quantify phenolic compounds and evaluate the allelopathic potential of extracts of Conyza sumatrensis on the germination of Bidens pilosa.

Studied species: Conyza sumatrensis (Retz.) E.Walker, Bidens pilosa L. (Asteraceae)

Study site: Palotina, state of Paraná, Brazil.

Methods: The aqueous extracts were prepared with shoot and root portions of $C$. sumatrensis in concentrations: 0 , 1,5 and $10 \%$. Germination and germination speed index were evaluated. The total flavonoids and phenols of the tested extracts were also quantified.

Results: With increasing concentrations of the extracts there was an increased inhibition of germination of B. pilosa and delays in the germination process. The extracts from the shoot of $C$. sumatrensis had a more expressive effect on seed germination when compared to the extracts obtained from the root. At concentration of $10 \%$, the extract from the shoot reduced in $83 \%$ the percentage of germination. This may be related to the higher concentration of total flavonoids and phenols found.

Conclusion: The allelopathic potential of $C$. sumatrensis plants can be considered since both shoot and root extracts inhibited and/or reduced the germination of B. pilosa.
\end{abstract}

Key words: Flavonoids, germination, interference, total phenol, weed.

\section{Resumen}

Antecedentes: Se deben considerar otras herramientas para el manejo de malezas además del uso de herbicidas. En este contexto, la identificación y el uso de compuestos alelopáticos merece atención.

Problema: Cuantificar compuestos fenólicos y evaluar el potencial alelopático de extractos de Conyza sumatrensis en la germinación de Bidens pilosa.

Especies de estudio: Conyza sumatrensis (Retz.) E.Walker, Bidens pilosa L. (Asteraceae)

Sitio de estudio: Palotina, estado de Paraná, Brasil.

Métodos: Los extractos acuosos se prepararon con porciones de brotes y raíces de C. sumatrensis en concentraciones: $0,1,5$ y $10 \%$. Se evaluaron la germinación y el índice de velocidad de germinación. También se cuantificaron los flavonoides y fenoles totales de los extractos probados.

Resultados: Con el aumento de las concentraciones de los extractos hubo una mayor inhibición de la germinación de $B$. pilosa y retrasos en el proceso de germinación. Los extractos del brote de C. sumatrensis tuvieron un efecto más expresivo sobre la germinación de las semillas en comparación con los extractos obtenidos de la raíz. En la concentración de $10 \%$, el extracto del brote redujo en $83 \%$ el porcentaje de germinación. Esto puede estar relacionado con la mayor concentración de flavonoides y fenoles totales encontrados.

Conclusión: El potencial alelopático de las plantas de C. sumatrensis puede considerarse ya que tanto los extractos de brotes como los de raíz inhibieron y/o redujeron la germinación de B. pilosa.

Palabras clave: Fenol total, flavonoides, germinación, interferencia, maleza. 
In addition to the selection of herbicide resistant weed biotypes, it is necessary to use other tools to manage weeds, as well as to prevent the selection of resistant weeds (Heap \& Duke 2018; Neve et al. 2018, Rosario-Lebron et al. 2019). In grain crops, weeds reduce yield and increase costs (Trezzi et al. 2015, Gazziero et al. 2019), a situation potentiated by the selection of resistant biotypes (Adegas et al. 2017). The decline in production is related to the competition for resources of the environment and may still be related to the release of allelopathic compounds (SouzaFilho 2014).

Allelopathy is the negative influence of a biomolecule, from a plant, on the morphophysiological development of other plants. When its interference is negative to the development of the same species, it can be classified as autotoxic, detrimental to the species itself, and/or heterotoxic when interfering with another plant species (Szczepański 1977, Mullik 2008). Allelopathic substances are released in the process of plant deterioration and/or root exudation as well as by volatilization. They may alter germination, because they cause disturbances to membrane permeability, DNA transcription and translation, affect the functioning of secondary messengers, respiration, the conformation of enzymes and receptors or their compilation (Ferreira \& Áquila 2000). Phenolic compounds are the most abundant class in plants and one of the main allelopathic substances inhibiting/retarding the germination process (Taiz \& Zeiger 2010).

Examples of allelopathy applied in agriculture have been observed in studies. Silva et al. (2016) observed the inhibition of lettuce germination using the extract of Conyza bonariensis (L.) Cronquist. In turn Reik (2018) observed that aqueous extracts of Eragrostis plana Nees reduced seed germination in Euphorbia heterophylla L. and Conyza sp.

Among the most diverse weed communities, those of the genus Conyza are composed of up to 80 species, which make up the family Asteraceae. They develop in the tropical and subtropical regions of America, as well as Europe and China (Sansom et al. 2013, Wang et al. 2017). The weeds hairy fleabane (C. bonariensis), horseweed (Conyza canadensis [L.] Croquist) and Sumatran fleabane (Conyza sumatrensis [Retz.] E.Walker) are among the most important in the world (Trainer et al. 2005). Conyza spp. annual, herbaceous plants (Lorenzi 2014) with high seed production, found in several agricultural environments, such as grain crops, one of the main weeds in these environments (Kissmann \& Groth 2007, Moreira \& Bragança 2011).

Studies on the allelopathic potential of Conyza spp. are important, since these plants are highly adaptable to current agricultural production systems. Besides that, studies indicate that allelopathy is one of the strategies for the success of weeds to reach the success in the process of interference with the cultivated plants, since compounds present in the shoot have an inhibiting/retarding effect on germination (Silva et al. 2016).

The eudicot weed hairy beggarticks (Bidens pilos $a$ L. and Bidens subalternans DC.) is present in several crops in Brazil, with importance in grain and sugarcane crops (Kissmann \& Groth 2007, Moreira \& Bragança 2011, Lorenzi 2014). Studies highlight B. pilosa as a weed of importance in soybean crops, for example, Ferreira et al. (2015) observed reduced dry mass of shoots and photosynthetic parameters of soybean in competition with B. pilosa.

It is believed that extracts of $C$. sumatrensis may have allelopathic effects on the germination of B. pilosa seeds. Thus, the aim of this study was to evaluate the allelopathic effect of compounds present on the shoot and root of C. sumatrensis on the germination of B. pilosa, and to quantify phenolic compounds present in extracts from shoot and root of C. sumatrensis.

\section{Materials and methods}

Collection of $\mathrm{C}$. sumatrensis plants and site description. The collection of $C$. sumatrensis was carried out in a commercial soybean crop during the off-season in the municipality of Palotina, state of Paraná (PR), Brazil (24 $20^{\prime} 44.54 " \mathrm{~S} 53^{\circ} 51^{\prime} 50.93 " \mathrm{~W}$ ), from July to August 2018. After collection, the plants were separated into shoots and roots. The samples were dried in a forced air circulation oven at $40{ }^{\circ} \mathrm{C}$ for 48 hours, to constant mass.

The study was conducted in a greenhouse at the Laboratory of Plant Physiology and Nutrition, Department of Agronomic Sciences and in the Laboratory of Organic Chemistry, Department of Engineering and Exact Sciences, Federal University of Paraná - Sector Palotina, Brazil.

Preparation of aqueous extracts from the shoots and roots of $\mathrm{C}$. sumatrensis. After drying the samples were ground in a Wiley knife mill (MA340, Marconi Equipamentos para Laboratórios Ltda, Piracicaba, SP, Brazil) with a $1 \mathrm{~mm}$ sieve and placed in externally black painted glass vials to avoid exposure to light. After grinding, distilled water was added to the samples and held for $24 \mathrm{~h}$ at room temperature. Then, they were filtered through cotton, thus obtaining cold aqueous extracts of the shoot and roots, separately.

Allelopathic effect of $\mathrm{C}$. sumatrensis extracts on the germination of $\mathrm{B}$. pilosa. The treatments consisted of aqueous extracts at the concentrations of $0,1,5$ and $10 \%$ $(w / v)$ (for 0 , we used distilled water only), with four replicates in a completely randomized design.

For the germination test, 50 seeds of B. pilosa were used per replicate, distributed in four gerbox plastic boxes, on two sheets of germination paper. The paper was moistened, 
at $2.5 \mathrm{x}$ its weight, with the respective concentrations of the aqueous extracts of $C$. sumatrensis. The boxes were kept in a B.O.D. germination chamber (MA415, Marconi Equipamentos para Laboratórios Ltda, Piracicaba, SP, Brazil) under photoperiod variation of $12 \mathrm{~h}$ and diurnal temperature of $30^{\circ} \mathrm{C}$ and night temperature of $20^{\circ} \mathrm{C}$.

The germination percentage and the germination speed index (GSI) were evaluated daily, up to 15 days after assembling the test. Seeds were considered as germinated when radicular protrusion exceeded $3 \mathrm{~mm}$. To calculate the GSI, the equation quoted by Borghetti \& Ferreira (2004) was used:

$$
\mathrm{GSI}=\sum \mathrm{D} / \mathrm{d}
$$

In which:

$\sum \mathrm{D}=$ total number of germinated seeds;

$\mathrm{d}=$ day of evaluation.

Data were analyzed according to Pimentel-Gomes \& Garcia (2002). After checking the assumptions, no data transformation required, germination of $B$. pilosa seeds, under aqueous extract of root and shoot at $10 \%$ of $C$. sumatrensis, was tested by analysis of variance (ANOVA) $(P<0.05)$, posteriorly the means were analysed by multiple comparisons by the Tukey's (1949) test $(P<0.05)$. For concentrations of roots and shoots extracts (separately) at germination and GSI, it was run regression analysis $(P<0.05)$. For this purpose, the Sisvar 5.6 software was used (Ferreira 2011).

In the model selection in the regression analysis, the following fit quality parameters were adopted: significant regression, regression deviations or lack of adjustment, significant t-test for all regression coefficients, residue analysis without trend, low coefficient of variation, high $\mathrm{R}$, and biological explanation. It was adjusted a decreasing linear fit for effect of shoot extracts on seed germination, also for effect of shoot and root extracts on GSI. For effect of root extracts on seed germination, it was adjusted a quadratic curve.

Quantification of phenolic compounds in extracts from the shoots and roots (10\% concentration) of $\mathrm{C}$. sumatrensis. For quantification of phenolic compounds, the following chemical reagents were used: Methyl Alcohol (lot: 2637-i, molecular weight 32.04g) (Alphatec Produtos Químicos Ltda., Santo André, SP, Brazil); Aluminum chloride (241.43g molecular weight) (Vetec Química Fina Ltda., Duque de Caxias, RJ, Brazil) and Folin-Ciocalteu reagent LOT 94905 (Dinâmica Química Contemporânea Ltda., Indaiatuba, SP, Brazil).

Among the phenolic compounds total flavonoids and phenols were quantified in the $C$. sumatrensis shoots and roots extracts $(10 \%$ concentration). To determine the analytical curve for flavonoids, a stock solution of methanol-based quercetin $(\mathrm{MeOH})$ at $500 \mathrm{ppm}$ and a solution of aluminum chloride $\mathrm{AlCl}_{3}$ at $5 \%(\mathrm{w} / \mathrm{v})$ were prepared.

The established curve points were at concentrations of $0.5 ; 5 ; 10 ; 50 ; 100 ; 300$ and $500 \mathrm{ppm}$. For this, an Orion AquaMate spectrophotometer (Thermo Fisher Scientific Brasil, São Paulo, SP, Brazil) at a wavelength of $425 \mathrm{~nm}$ was used. The solvent used was distilled water. For determination of flavonoids, crude extracts were prepared $24 \mathrm{~h}$ in advance. The test solution was prepared adding the following to a $10 \mathrm{~mL}$ penicillin flask: $2.8 \mathrm{~mL} \mathrm{H}_{2} \mathrm{O}+0.1 \mathrm{~mL}$ $\mathrm{MeOH}+1 \mathrm{~mL} 5 \% \mathrm{AlCl}_{3}+0.1 \mathrm{~mL}$ sample. Once the reaction became sensitive, test solution was stored for $1 \mathrm{~h}$ protected from light to stabilize the reaction and subsequent reading of the samples. Flavonoids content from the root and shoot extracts was obtained in ppm by triplicate. Data were tested by ANOVA $(P<0.05)$ using the Sisvar 5.6 software (Ferreira 2011).

For quantification of total phenols, the methodology of Folin-Denis (Shanmugam \& Thangaraj 2013) was adopted. First, it became necessary to establish an analytical curve. To determine the curve, a stock solution of Gallic acid (500 $\mathrm{ppm})$ in methanol $(\mathrm{MeOH})$ was prepared. A solution of $5 \%$ calcium carbonate $(\mathrm{w} / \mathrm{v})$ was also prepared. The established curve points were at $5 ; 10 ; 50 ; 100 ; 300$ and $500 \mathrm{ppm}$. For this purpose, an Orion AquaMate spectrophotometer at a wavelength of $760 \mathrm{~nm}$ was used. The solvent used was distilled water.

For determination of total phenols, the crude extracts were prepared $24 \mathrm{~h}$ in advance. For the preparation of the test solution, $2.8 \mathrm{~mL} \mathrm{H}_{2} \mathrm{O}+0.1 \mathrm{~mL}$ Folin-Ciocalteu $+1 \mathrm{~mL}$ $5 \% \mathrm{Na}_{2} \mathrm{CO}_{3}+0.1 \mathrm{~mL}$ sample was added to a $10 \mathrm{~mL}$ penicillin flask. Once the reaction is sensitive, the samples were stored for $1 \mathrm{~h}$ protected from light, for stabilization of the reaction and subsequent reading of the samples. The triplicate data obtained in ppm of root and shoot extracts were tested by ANOVA $(P<0.05)$ using the Sisvar 5.6 software (Ferreira 2011).

\section{Results}

Allelopathic effect of $\mathrm{C}$. sumatrensis extracts on the germination of B. pilosa. Aqueous extracts from the shoots of $C$. sumatrensis reduced the percentage of B. pilosa seed germination. It was possible a decreasing linear fit, with increasing concentration of the extracts, it was observed a reduction in germination (Figure 1). For the extracts from C. sumatrensis roots, there was a quadratic curve adjustment, with reduction for $>5 \%$ of concentration (Figure 2). The shoot extract affected more the germination percentage of the seeds in comparison with the root extract (at $10 \%$ concentration) (Table 1).

It was possible a decreasing linear fit for GSI, with increasing concentration of the extracts from the shoots of 
C. sumatrensis, there was a reduction in the GSI of seeds of B. pilosa (Figure 3). The highest concentration (10\%) resulted in a higher delay in seed germination, with a value 5 times lower in comparison to control $(0 \%)$.

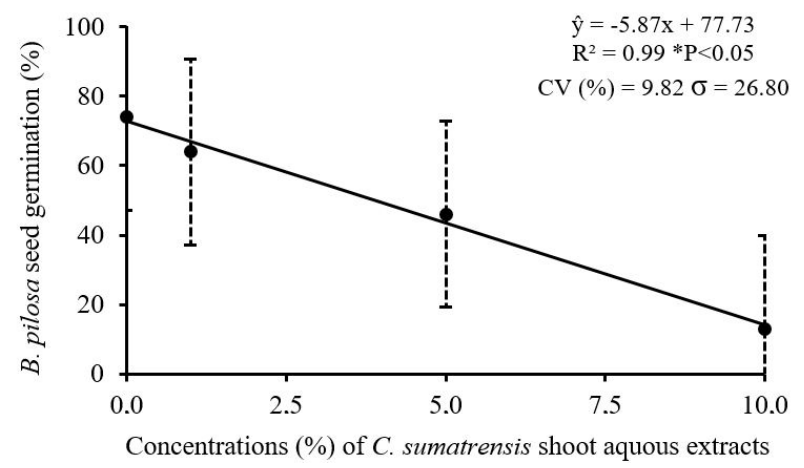

Figure 1. Percentage of $B$. pilosa seed germination under different concentrations of $C$. sumatrensisshoot aqueous extracts.

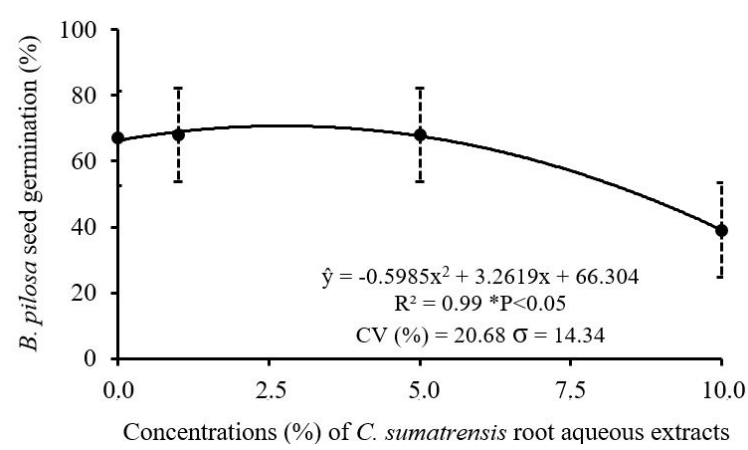

Figure 2. Percentage of $B$. pilosa seed germination under different concentrations of $C$. sumatrensisroot aqueous extracts.

As for the shoot extract, results for the GSI of B. pilosa seeds using root extracts also fit a decreasing linear model. With increasing concentration of the extracts from the roots of $C$. sumatrensis plants, there was a reduction in the GSI of seeds of B. pilosa (Figure 4).

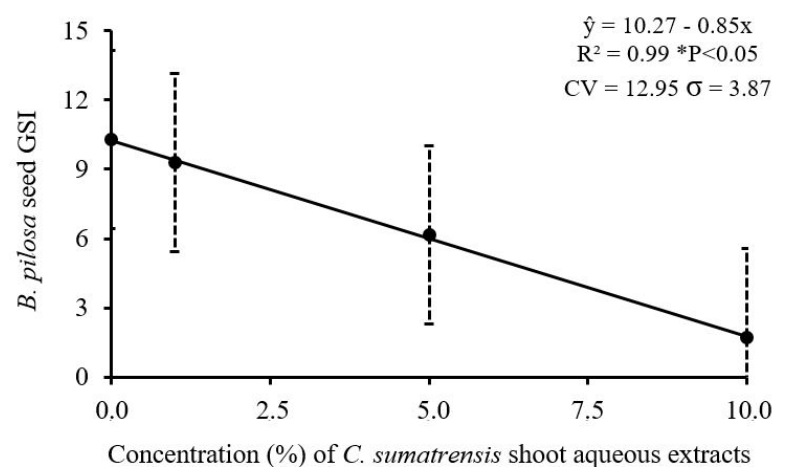

Figure 3. B. pilosa seed germination rate index under different concentrations of $C$. sumatrensisshoot aqueous extracts.

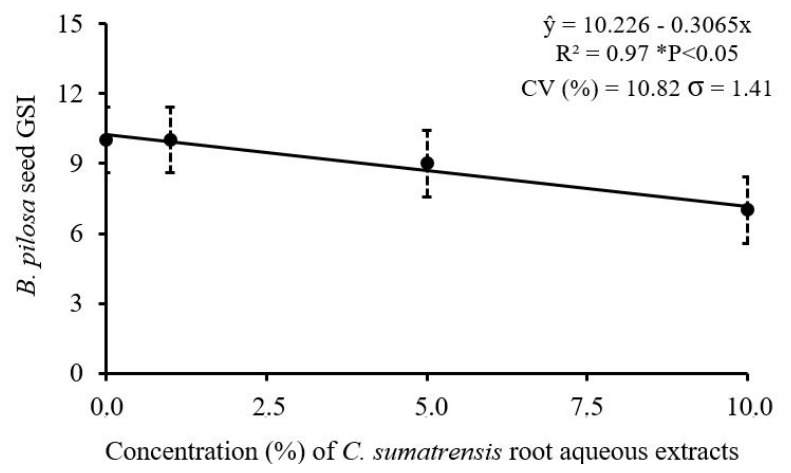

Figure 4. B. pilosa seed germination rate index under different concentrations of $C$. sumatrensisroot aqueous extracts.

Quantification of phenolic compounds in extracts from the shoot and root (10\% concentration) of $\mathrm{C}$. sumatrensis. The shoot extracts at $10 \%$ concentration had a flavonoid content of $290 \mathrm{ppm}$. While for the roots extracts, the flavonoid content observed was $9.2 \mathrm{ppm}$, different values by the $F$-test $(P<0.05)$. The highest concentrations of total phenols were also identified in the shoot extracts, presenting $312.04 \mathrm{ppm}$, while the roots extract presented a concentration of only $108.04 \mathrm{ppm}$, different values by the $F$-test $(P<0.05)$ (Table 2).

Table 1. Mean values of germination percentage ( $\% \mathrm{G})$ of B. pilosa seeds under aqueous extract of roots and shoot $(10 \%$ concentration) of C. sumatrensis.

\begin{tabular}{lc}
\hline \multicolumn{1}{c}{ Treatments } & \% G \\
\hline Control & $70 \mathrm{a}$ \\
Extract $\mathbf{1 0} \%$ of roots & $39 \mathrm{~b}$ \\
Extract $\mathbf{1 0} \%$ of shoot & $13 \mathrm{c}$ \\
Standard deviation & 24.89 \\
CV (\%) & 8.40 \\
F & $209.40 *$ \\
\hline
\end{tabular}

*Means followed by different letters in the column differ by Tukey's (1949) test $(P<0.05)$.

Table 2. Phenolic compounds (ppm) in extracts from the shoot and roots (10\% concentration) of C. sumatrensis.

\begin{tabular}{lcc}
\hline \multicolumn{1}{c}{ Treatments } & Flavonoids content & Total phenols \\
\hline Extract $\mathbf{1 0} \%$ of roots & 9.20 & 108.04 \\
Extract $\mathbf{1 0} \%$ of shoot & 290.00 & 312.04 \\
Standard deviation & 153.93 & 113.02 \\
CV (\%) & 4.71 & 9.06 \\
$\boldsymbol{F}$ & $2,377.59^{*}$ & $172.46^{*}$ \\
\hline
\end{tabular}

* Means, at same column, differ by $F$-test $(P<0.05)$. 


\section{Discussion}

The reduction in the germination process can be related to the increase in the concentrations of toxic compounds. It is characterized the inhibitory allelopathic effect of C. sumatrensis plants on the germination of B. pilosa. Allelopathy is classified as interference, since there is no competition for essential factors for germination and seedling development, but rather the release of compounds into the environment that alter patterns and conformations at cellular levels of neighboring species, leading to suppression of these plants (Silva 2012).

Different studies demonstrate the sensitivity of plants of the genus Bidens to plant extracts. Results similar to those found in this study were reported by Rizzardi et al. (2008), in which aqueous extracts from the shoots of canola reduced the germination of Bidens sp. to 88 and $97 \%$, at 6 and $8 \%$ (w/v) concentration, respectively. Reik (2018) also observed a reduction of germination percentages of $B$. pilosa under the influence of the crude aqueous extract of Avena strigosa Schreb. at concentrations above $30 \%$ (corresponding to $7.5 \% \mathrm{w} / \mathrm{v})$.

Shaukat et al. (2003) evaluated the allelopathic potential of horseweed and found that the aqueous extract of C. canadensis seedlings at $7.5(\mathrm{w} / \mathrm{v})$ totally inhibited tomato germination. This result corroborates those obtained herein, showing that there is interference between different species.

The germination speed index (GSI) may be indicative of seed vigor according to its germination pattern. High GSI indicates a fast and uniform germination; in this situation the seeds are less exposed to soil pathogens, which ensures competitive advantages over the neighboring species (PiñaRodrigues et al. 2004). The increased concentration of the extracts delayed the germination process. The finding of reduction in GSI indicates the interference of the allelochemicals contained in the extracts on germination.

The delay in germination according to the rates of the aqueous extracts is an advantage over the other neighboring species, with advantages in the competition. This may explain the fact that areas with dense populations of Conyza are practically free of other weeds (Djurdjević et al. 2011).

Flavonoid compounds, especially quercetin, may be responsible for the inhibitory effect on seed germination. Paszkowski \& Kremer (1988), found that the aqueous extract of Abutilon theophrasti Medik. significantly inhibited/retarded the germination of cress, radish and soybean. The phenolic compounds identified in larger expressions in the extracts were: catechins, epicatechins and quercetin.

This proportion in the amount of total phenols and flavonoids present in the extracts from the shoots helps to understand the event of inhibition and retardation of the germinative process of the seeds tested. This indicates that there is an interaction of different secondary metabolites, which result in the inhibition of germination.

Although phenolic compounds are frequently released into the environment via the root system, stress bound to this organ will not necessarily increase the concentration of these compounds. The relationship in increasing phenolic compound production seems to be more associated with increases in solar radiation intensity, since phenolic compounds act to protect against UV radiation. Secondary metabolites, as the phenolic compounds studied, are expressed as a function of the chemical interface between the synthesizing organ and the environment (Gobbo-Neto \& Lopes 2007), it may be due to this characteristic that the observed levels of the phenolic compounds in the extracts were very low compared to the extracts from the shoots.

The data obtained herein corroborate the results in the literature, where researchers have identified that phenolic compounds such as: caffeic acid, chlorogenic acid, gallic acid and flavonoid compounds, including quercetin, are responsible for the inhibition of germination (CantanhedeFilho et al. 2017, Pereira et al. 2018).

Among the dysfunctions triggered by flavonoid compounds, stands out the modulation in the levels of reactive oxygen species, which leads to the peroxidation of membranes and fundamental enzymes in the germination process (Ferreira \& Áquila 2000, Pereira et al. 2018). But also, phenols, which exert interference in the germination process as a whole, in addition to causing damage to membrane permeability by raising oxidative enzyme activity as well as early root lignification, interfering with the process of organ absorption and development (Bubna et al. 2011, Pereira et al. 2018).

In this way, this characterization helps us to understand and interpret the values obtained in germination tests. The most effective results regarding inhibition/delay were observed in the treatments testing extracts from the shoots, which are probably because such extracts come directly from the organ in which the compounds are synthesized.

The shoot and root extracts of $C$. sumatrensis presented an allelopathic potential in inhibiting and reducing the germination of $B$. pilosa. The extracts from the shoots reduced the germination more intensely, as well as had the highest concentrations of molecules of total flavonoids and phenols, which may be associated with the inhibitory effect. Our findings serve as support for research in the area of alternative weed control management.

As already mentioned, our results can explain the fact that areas with dense populations of Conyza are practically free of other weeds. This specie is an important weed, especially in grain crops, and its interference on crops, among other factors, may also be related to the release of allelopathic compounds. 


\section{Literature cited}

Adegas FS, Vargas L, Gazziero DLP, Karam D, Silva AF, Agostinetto D. 2017. Impacto econômico da resistência de plantas daninhas a herbicidas no Brasil. Embrapa Soja. Circular técnica 132.

Borghetti F, Ferreira AG. 2004. Interpretação de resultados de germinação. In: Ferreira $\mathrm{AG}$, Borghetti $\mathrm{F}$, eds. Germinação: do básico ao aplicado. Porto Alegre. Artmed. pp. 209-222. ISBN 85-363-0383-2

Bubna GA, Lima RB, Zanardo DYL, Santos WD, Ferrarese MDLL, Ferrarese-Filho O. 2011. Exogenous caffeic acid inhibits the growth and enhances the lignification of the roots of soybean (Glycine max). Journal of Plant Physiology 168: 1627-1633. DOI: https://doi.org/10. 1016/j.jplph.2011.03.005

Cantanhede-Filho JA, Santos SL, Guilhon PSMG, Zoghbi BMG, Ports SP, Rodrigues SCI. 2017. Triterpenoids, phenolics and phytotoxic effects from Eugenia flavescens DC (Myrtaceae) leaves. Química Nova 40: 252-259. DOI: http://dx.doi.org/10.21577/0100-4042. $\underline{20160190}$

Djurdjević L, Mitrović M, Gajić G, Jarić S, Kostić O, Oberan L, Pavlović P. 2011. An allelopathic investigation of the domination of the introduced invasive Conyza canadensis L. Flora-Morphology, Distribution, Functional Ecology of Plants 206: 921-927. DOI: https://doi.org/10.1016/j.flora.2011.06.001

Ferreira DF. 2011. Sisvar: a computer statistical analysis system. Ciência e Agrotecnologia 35: 1039-1042. DOI: http://dx.doi.org/10.1590/S1413-70542011000600001

Ferreira AG, Aquila MEA. 2000. Alellopathy: an emerging topic in ecophysiology. Revista Brasileira de Fisiologia Vegetal 12: 175-204.

Ferreira EA, Matos CDC, Barbosa EA, Melo CAD, Silva DV, Santos JB. 2015. Physiology aspects of transgenic soybean submitted to competition with weed. Revista de Ciências Agrárias / Amazonian Journal of Agricultural and Environmental Sciences 58: 115-121. DOI: http:// dx.doi.org/10.4322/rca.1745

Gazziero DLP, Adegas FS, Silva AF, Concenço G. 2019. Estimating yield losses in soybean due to sourgrass interference. Planta Daninha 37: e019190835. DOI: http://dx.doi.org/10.1590/s0100-83582019370100047

Gobbo-Neto L, Lopes NP. 2007. Medicinal plants: factors of influence on the content of secondary metabolites. Química Nova 30: 374-381. DOI: http://dx.doi.org/10. 1590/S0100-40422007000200026

Heap I, Duke SO. 2018. Overview of glyphosate-resistant weeds worldwide. Pest Management Science 74: 1040-1049. DOI: https://doi.org/10.1002/ps.4760

Kissmann KG, Groth D. 2007. Plantas infestantes $e$ nocivas. Basf, São Paulo. CD ROM.
Lorenzi H. 2014. Manual de identificação e controle de plantas daninhas: plantio direto e convencional. Brasil. Plantarum. ISBN: 978-85-86714-45-0

Moreira HJC, Bragança HNP. 2011. Manual de identificação de plantas infestantes. Campinas. FMC Agricultural Products.

Mullik AZ. 2008. Allelopathy: Advances, challenges and opportunities. In: Zeng RS et al. eds. Allelopathy in sustainable agriculture and forestry. New York. Springer, pp. 25-40. ISBN 978-0-387-77337-7

Neve P, Barney JN, Buckley Y, Cousens RD, Graham S, Jordan NR, Shaw J, Lawton Rauh A, Liebman M, Mesgaran MB, Schut M, Shaw J, Storkey J, Baraibar B, Baucom RS, Chalak M, Childs DZ, Christensen S, Eizenberg H, Fernández Quintanilla C, French K, Harsch M, Heijting S, Harrison L, Loddo D, Macel M, Maczey N, Mortensen D, Necajeva J, Peltzer DA, Recasens J, Renton M, Riemens M, Sønderskov M, Williams M. 2018. Reviewing research priorities in weed ecology, evolution and management: a horizon scan. Weed Research 58: 250-258. DOI: https://doi.org/10.1111/ wre. 12304

Paszkowski WL, Kremer RJ. 1988. Biological activity and tentative identification of flavonoid components in velvetleaf (Abutilon theophrasti Medik.) seed coats. Journal of Chemical Ecology 14: 1573-1582. DOI: https://doi.org/10.1007/BF01012523

Pereira JC, Paulino CL, Granja B, Santana AEG, Endres L, Souza RC. 2018. Allelopathic potential and identification of secondary metabolites in extracts of Canavalia ensiformis L. Revista Ceres 65: 243-252. DOI: http:// dx.doi.org/10.1590/0034-737x201865030004

Pimentel-Gomes F, Garcia CH. 2002. Estatística aplicada a experimentos agronômicos e florestais: exposição com exemplos e orientações para uso de aplicativos. Piracicaba. Fealq, ISBN 85-7133-014-X

Piña-Rodrigues FCM, Figliolia MB, Peixoto MC. 2004. Teste de qualidade. In: Ferreira AG, Borghetti F, eds. Germinação: do básico ao aplicado. Porto Alegre. Artmed. pp. 283-297. ISBN 85-363-0383-2

Reik GG. 2018. Fitotoxicidade e eficácia de extratos aquosos aplicados no manejo de plantas daninhas em culturas de verão. MSc. Thesis, Universidade Federal da Fronteira Sul.

Rizzardi MA, Neves R, Lamb TD, Johann LB. 2008. Potencial alelopático da cultura da canola (Brassica napus L. var. oleifera) na supressão de picão-preto (Bidens sp.) e soja. Current Agricultural Science and Technology 14: 239-248. DOI: http://dx.doi.org/10.185 39/cast.v14i2.1907

Rosario-Lebron A, Leslie AW, Yurchak VL, Chen G, Hooks CR. 2019. Can winter cover crop termination practices impact weed suppression, soil moisture, and yield in no- 
till soybean [Glycine max (L.) Merr.]? Crop Protection 116: 132-141. DOI: https://doi.org/10.1016/j.cropro. 2018.10.020

Sansom M, Saborido AA, Dubois M. 2013. Control of Conyza spp. with glyphosate - a review of the situation in Europe. Plant Protection Science 49: 44-53. DOI: https://doi.org/10.17221/67/2011-PPS

Shanmugam S, Thangaraj P. 2013. Total phenolic content, free radical scavenging and antimicrobial activities of Passiflora subpeltata seeds. Journal of Applied Pharmaceutical Science 3: 67-72. DOI: https://doi.org/ 10.7324/JAPS.2013.3412

Shaukat SS, Munir N, Siddiqui IA. 2003. Allelopathic responses of Conyza canadensis (L.) Cronquist: A cosmopolitan weed. Asian Journal of Plant Sciences 2: 1034-1039. DOI: http://dx.doi.org/10.3923/ajps.2003. $\underline{1034.1039}$

Silva PSS. 2012. Allelochemicals in plants and the use of allelopathy in agronomy. Biotemas 25: 65-74. DOI: https://doi.org/10.5007/2175-7925.2012v25n3p65

Silva TA, Delias D, Pedó T, Abreu ES, Villela FA, Aumonde TZ. 2016. Phytotoxicity of Conyza bonariensis (L.) Cronquist extract on the seeds and lettuce seedlings physiological performance. Iheringia. Série Botânica 71: 213-221.

Souza-Filho APS. 2014. Alelopatia: Princípios básicos e mecanismos de interferências. In: Monquero PA, org.

\section{Associated Editor: Joel Flores}

Authors' contribution: PJF data collection and article writing. PCZ conceptualization, data analysis and article review. AJPA conceptualization, data analysis and article review. IGR conceptualization and article review. AFMS article writing. LPA article review. AHV data collection. RP article review.
Aspectos da biologia e manejo das plantas daninhas. São Carlos. Rima - SBCPD, pp. 83-102. ISBN 978-85-7656-298-6

Szczepański AJ. 1977. Allelopathy as a means of biological control of water weeds. Aquatic Botany 3: 193-197. DOI: https://doi.org/10.1016/0304-3770(77)90019-5

Taiz L, Zeiger E. 2010. Plant physiology. Sunderland, USA. Sinauer Associates. ISBN-13: 978-0878938667

Trainer GD, Loux MM, Harrison SK, Regnier E. 2005. Response of horseweed biotypes to foliar applications of cloransulam-methyl and glyphosate. Weed Technology 19: 231-236. DOI: https://doi.org/10.1614/WT-04-127R3

Trezzi MM, Vidal RA, Patel F, Miotto Jr E, Debastiani F, Balbinot Jr AA, Mosquen R. 2015. Impact of Conyza bonariensis density and establishment period on soyabean grain yield, yield components and economic threshold. Weed Research 55: 34-41. DOI: https:// doi.org/10.1111/wre.12125

Tukey JW. 1949. Comparing individual means in the analysis of variance. Biometrics 5: 99-114. DOI: https:// doi.org/10.2307/3001913

Wang C, Jiang K, Zhou J, Liu J. 2017. Allelopathic suppression by Conyza canadensis depends on the interaction between latitude and the degree of the plant's invasion. Acta Botanica Brasilica 31: 212-219. DOI: http://dx.doi.org/10.1590/0102-33062017abb0045 